\title{
PIECES FRAMEWORK ON THE IMPLEMENTATION OF RAPID ENUMERATION AND EVALUATION INFORMATION SYSTEM OF 2020 POPULATION CENSUS
}

\author{
Rizka Ita Yuanita \\ Seksi Jaringan dan Rujukan Statistik \\ BPS Provinsi Jawa Barat \\ www.jabar.bps.go.id \\ riz.itayu@gmail.com
}

\begin{abstract}
In September 2020, Statistics Indonesia (BPS RI) carried out a major activity, namely the 2020 Population Census At the SP2020 data processing stage, Mobile Capture is one of the options for photographing data collection results. During the use of mobile capture, BPS West Java Province encountered several obstacles. West Java Province BPS created an application called the Rapid Enumeration dan Evaluation 2020 Population Census Information System (Sicepat32 SLS) to monitor the attainment of enumeration to the smallest level (local environmental unit). To find out whether Sicepat32 SLS is working and functioning properly, it is necessary to evaluate the performance of the information system. The purpose of this study is to measure the level of user satisfaction with the application of Sicepat32 SLS and to assess whether Sicepat32 SLS can meet the needs of users. In this study, the PIECES Framework analysis model will be used and has produced an assessment score in the Performance domain of 4.07; Information and Data of 4.17; Economy 4.1; Control and Security with a score of 4.03; Efficiency with a score of 4.18 and Service getting a score of 4.18
\end{abstract}

Keywords: analyze, pieces framework, user satisfaction, information system, mobile capture

Abstrak-Pada bulan September 2020 Badan Pusat Statistik (BPS) melaksanakan kegiatan besar yaitu Sensus Penduduk 2020. Pada tahap pengolahan data SP2020, Mobile Capture menjadi salah satu pilihan untuk memotret hasil pendataan. Dalam penggunaan mobile capture, BPS Provinsi Jawa Barat menemui beberapa kendala. BPS Provinsi Jawa Barat membuat aplikasi Sistem Informasi Pencacahan dan Evaluasi Pencacahan secara Cepat SP2020 (Sicepat32 SLS) untuk memantau pencapaian pencacahan hingga ke tingkat terkecil yaitu Satuan Lingkungan Setempat (SLS). Untuk mengetahui apakah Sicepat32 SLS sudah bekerja dan berfungsi dengan baik, maka perlu dilakukan evaluasi terhadap kinerja sistem informasi. Tujuan dari penelitian ini adalah untuk mengukur tingkat kepuasan pengguna terhadap aplikasi Sicepat32 SLS, dan untuk menilai apakah SLS Sicepat32 dapat memenuhi kebutuhan pengguna. Dalam studi ini akan digunakan model analisis Kerangka Kerja PIECES dan menghasilkan skor penilaian pada domain Kinerja sebesar 4,07; Informasi dan Data 4.17; Ekonomi 4.1; Kontrol dan Keamanan dengan skor 4,03; Efisiensi dengan skor 4,18 dan Layanan mendapatkan skor 4,18

Kata kunci: analisa, framework pieces, kepuasan pengguna, sistem informasi, mobile capture

\section{INTRODUCTION}

The development of increasingly advanced technology makes organizations/ institutions take advantage of the ease of use. The rapidity of technology is one of the pillars of the success of an organization/ institution in obtaining data and processing data. As quoted from the page http://www.bps.go.id/sp2020/ (accessed 24 Dec 2021) September is the implementation of the 2020 Population Census using the interview method (field data collection). The 2020 Population Census (SP2020) aims to obtain strategic and up-to-date basic population data in the framework of leading to Satu Data Indonesia (BPS Provinsi Jawa Barat, 2021). The data collection stage is one of the stages that must be carried out in a census or survey activity and is one of the factors in the success of the census implementation (Takdir, 2019). At the census data processing stage, there are several types of data processing, including processing using Mobile Capture. The use of Mobile Capture is a breakthrough in the Android-based data processing stage. Mobile Capture is used to record the Population List recapitulation data in the SP2020DP1 and SP2020-DP2 documents (SIS, 2020).

In the activity of recording census data with mobile capture, BPS Provinsi Jawa Barat felt that there were many obstacles experienced by census officers during the data collection stage, ranging from image requirements that had to be cleared, the officer's handwriting was able to be read by systems, networks constraints or difficult to signals. Reached when sending images and then causing 
failed submissions, photo-taking errors, and having to wait a long time for the reject process from the server. Based on the description of the identification problems above, BPS Provinsi Jawa Barat took steps by building a system called Rapid Enumeration and Evaluation Information System of 2020 Population Census (Sicepat 32 SLS) to overcome problems in the use of mobile capture.

To find out the level of satisfaction of Sicepat32 SLS users at the BPS Regency/ Municipality, it is necessary to process the analysis and evaluation of users about the performance of the system. According to (Tullah \& Hanafri, 2014), Evaluation is a planned activity to assess a problem that occurs using instruments, and the results can be compared with benchmarks to obtain results or conclusions so that problem-solving solutions are found to solve problems that occur. Information system evaluation can be done in different ways and also at different levels, depending on the purpose of the evaluation that will be used. The purpose of this study is to measure the level of satisfaction by implementing Sicepat32 SLS for users, especially BPS Regency/ Municipality.

Research on the Sicepat32 SLS application focuses on system performance using the PIECES Framework Method. According to (Dewi, 2018) Pieces analysis is a method used to obtain more specific points. Meanwhile, according to (Dwiyantoro, 2019) quoted from (Fatta, 2007) Pieces analysis is a method used to identify problems that occur, by analyzing problems with information system performance, economy, application security, efficiency, and customer service. Also, from research conducted by (B Indra G, Hayatullah H, 2013) Pieces analysis is a tool in analyzing computer-based information systems, where there are 6 domains to analyze the system, namely Performance, Information and Data, Economy, Control and Security, Efficiency, and Service.

The benefits to be achieved in this research are:

1. Can provide system evaluation based on pieces analysis method so that policymakers can find out the extent of effectiveness and efficiency after using information systems,

2. Can find out whether the information system in question is following user needs and can produce quality information.

\section{MATERIALS AND METHODS}

\section{Information Systems}

Definition of the System according to (Sutabri, 2012) is a collection of elements or components that are organized, mutually integrated, interacting, and integrated. According to (Jogiyanto, 2017) an Information system is a system within an organization that meets the needs of daily processing, managerial operations of an organization.

Technically, information systems can be defined as a set of components or elements that are interconnected and process information to support decision-making in an organization.

\section{Research methodology}

The method used in this study uses qualitative methods and inductive data analysis. As stated by (Sugiyono, 2015) The qualitative research method is a method based on the philosophy of postpositivism, used to observe the condition of natural objects, where the researcher is the key instrument, data collection techniques are carried out in combination, data analysis is inductive/ qualitative, and the results of qualitative research emphasize the meaning rather than generalization. The reason for using inductive data analysis is because the inductive process can see and understand the subject and object of research which includes people or institutions based on existing facts.

\section{Sample Selection}

\section{a. Population}

From(Sugiyono, 2015) The world population comes from English, which means population, which means population, the population is an area of generalization consisting of objects/subjects that have certain qualities and characteristics that the researcher determines to study and then draw conclusions. The population in this study were users who used the evaluation information system and the results of the enumeration which consisted of 40 Sicepat32 SLS users.

b. Sample

Sample or it can be said that the sample is part of the total population and the characteristics possessed by that population. The sampling technique used in this study was purposive sampling, namely the sampling technique with certain considerations. This means that each subject taken from the population is chosen deliberately based on certain goals and considerations (Sugiyono, 2015). The samples chosen in this study were 30 respondents.

\section{Method of collecting data}

In this study, the authors performed data collection techniques by:

1. Interview

Interviews or interviews were conducted with census officers who had used mobile capture.

2. Questionnaire 
Collecting data by giving questionnaires to user respondents from Sicepat 32 SLS.

\section{Data Measurement Method}

To get evaluation results, a measurement method is needed. The scale of the questionnaire was made to provide questions and statements of respondents using a Likert scale. According to (Sugiyono, 2015), The Likert scale is used to measure a person's approval and disagreement with a program plan, program implementation, or the success rate of a program. Table 1 Likert Scale, showing the dimensions of the Likert scale starting from the answer Strongly Agree with a score of 5 to the answer Strongly Disagree with a score of 1.

Table 1. Likert Scale

\begin{tabular}{ccc}
\hline Answer & Acronym & Score \\
\hline $\begin{array}{c}\text { Strongly } \\
\text { agree }\end{array}$ & SS & 5 \\
\hline Agree & S & 4 \\
\hline Doubtful & R & 3 \\
\hline Disagree & TS & 2 \\
\hline $\begin{array}{c}\text { Strongly } \\
\text { Disagree }\end{array}$ & STS & 1 \\
\hline
\end{tabular}

Equation (1) is used to obtain the average level of user satisfaction:

$R K=\frac{\text { Jumlah skor jawaban kuesioner }}{\text { Total Jumlah Kuesioner }}$

RK = Average Satisfaction

In determining the level of user satisfaction, researchers use theory (Robert S. Kaplan; David P. Norton, 2000) shown in Table 2. Satisfaction Scale, with the following levels:

Table 2. Satisfaction Scale

\begin{tabular}{cc}
\hline Value Range & Category \\
\hline $1-1.79$ & Very Dissatisfied \\
$1.8-2.59$ & Not satisfied \\
$2.6-3.39$ & Doubtful \\
$3.4-4.91$ & Satisfied \\
$4.92-5$ & Very satisfied \\
\hline
\end{tabular}

\section{Pieces Framework Method}

PIECES Framework is a framework used to classify a problem, opportunities, and directives contained in the scope definition section of analysis and system design (Supriyatna \& Informatika, 2015). The Pieces Framework can be used as a tool to evaluate the system in use and to see opportunities for improvement (Hadisaputro \& Setyaningsih, 2019). In the Pieces Framework, six domains are used to analyze information systems and are represented by each letter, namely Performance, Information and Data, Economic, Control, Efficiency, and Service. From (Fatoni, Adi, \& Widodo, 2020), the Pieces Framework method is a framework that includes 6 categories that have been classified in problem-solving. Quoting from (Lokapitasari Belluano, Indrawati, Harlinda, Tuasamu, \& Lantara, 2019) PIECES allows for continuous improvement of joint care through human resource development (HRD).

From (Aji \& Hidayatullah, 2019), Performance measurement is done to find out how reliable the performance or performance of the system is. Measurement of Information and Data is used to determine the extent to which a system can produce output, especially in presenting the information needed by the organization. Domain Economic measures how effective the costs incurred by the organization with the application of the system. Control measures the level of ease of data access and data security. Efficiency measures whether a system with minimal input can produce large outputs. Services measures whether users are satisfied with the services of a system.

\section{RESULTS AND DISCUSSION}

\section{Identification of Mobile Capture Problems}

During the 2020 Population Census (September) at the data processing stage, the BPS Provinsi Jawa Barat -IT team identified constraints that arise when census officers use mobile capture. Mobile capture that is installed on the officer's gadget, for 1.5 months of use, many obstacles experienced by officers so that it was not optimal in processing data.

Table 3. Problem Identification shows a list of problems identified by the researcher. Census officers who have finished collecting data or verifying the population in the field are required to capture or take a picture of the front page of the enumeration document, then send it to the server. Requirements for submitted images must be meets criteria such as not being blurry or blurred, photos with a clear resolution, non-curved documents, and easy-to-read writing.

Table 3. Problem Identification

\begin{tabular}{|c|c|}
\hline No. & Identification Results \\
\hline 1 & $\begin{array}{l}\text { Failed to install Mobile Capture on the } \\
\text { smartphone }\end{array}$ \\
\hline 2 & $\begin{array}{l}\text { Failed to login to the mobile capture } \\
\text { application }\end{array}$ \\
\hline 3 & Submit to the server is time-consuming \\
\hline 4 & $\begin{array}{l}\text { Census officers must wait for the } \\
\text { rejection from the Center (waiting time } \\
+1-2 \text { weeks) }\end{array}$ \\
\hline 5 & Synchronization failed \\
\hline
\end{tabular}




\section{Sicepat32 System Analysis}

Sicepat32 SLS was built with the Laravel framework with the PHP programming language and MySQL database. Sicepat32 SLS is web-based and used by 19 Regencies/ Municipalities in Provinsi Jawa Barat. The users of Sicepat32 are Statistics Processing and Dissemination Integration Section (IPDS), Social Section, and Census Coordinator.

Sicepat32 SLS users will upload data on the Sicepat32 SLS web at each Local Environmental Unit (SLS). Then the dashboard display will automatically display the cumulative population per Regency/ Municipality. There are 2 roles in Sicepat32 SLS, namely the role as Admin and the role as Census Coordinator. Each Census Coordinator is given access rights to input data on the number of men and women in each SLS that is supervised. In the Sicepat32 SLS application, it will immediately calculate the sex ratio based on the data input from the Census Coordinator.

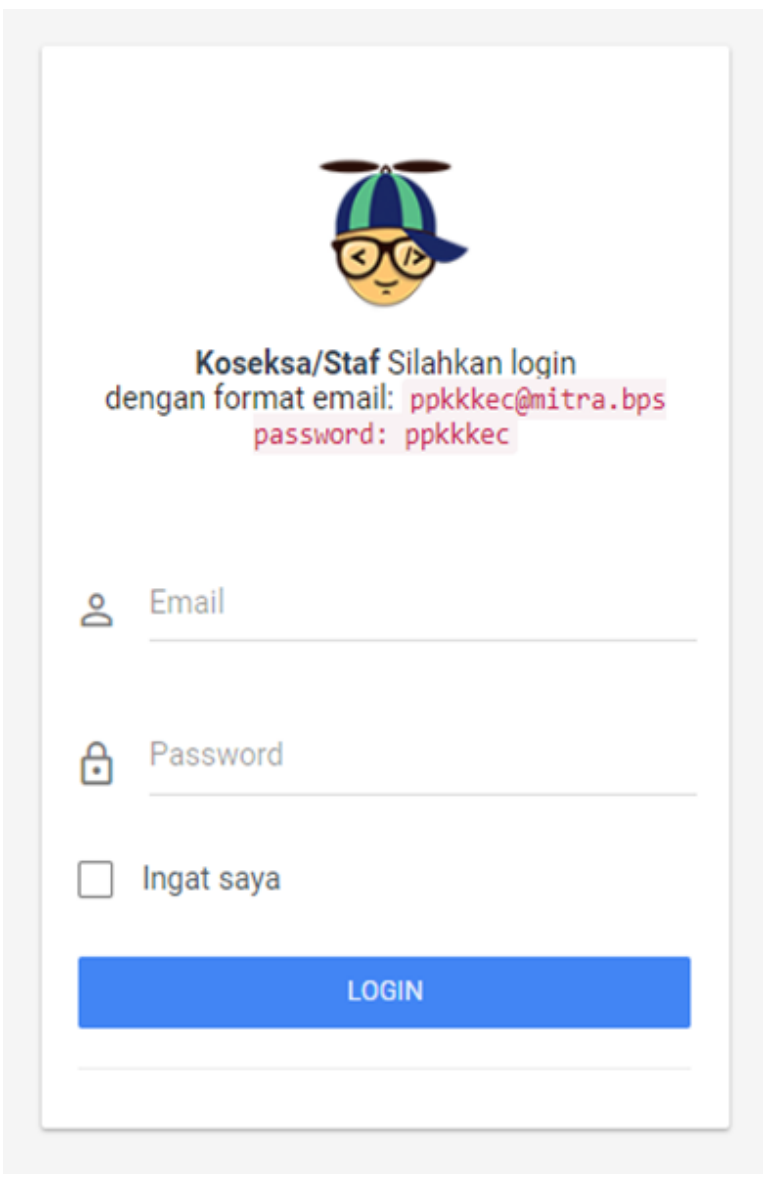

Figure 1. Display Login Sicepat32 SLS

Figure 1 Login view of Sicepat32 SLS used for access into the system functions to regulate access from users. On the Home page, a graph appears that can be broken down to the district level.

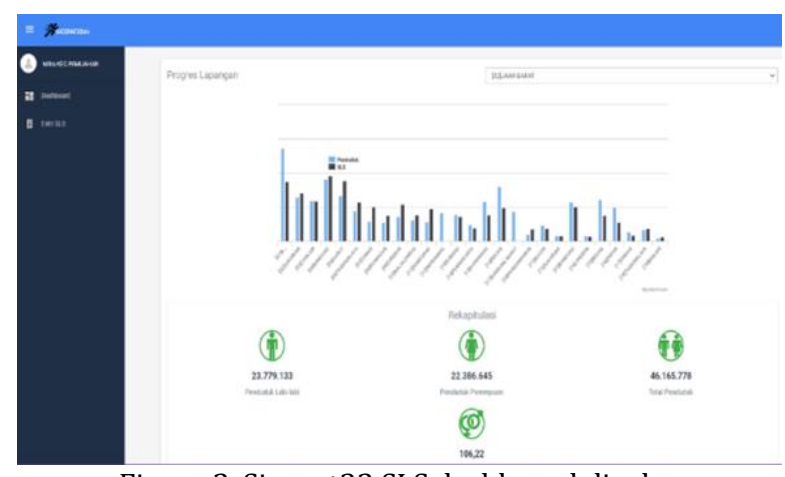

Figure 2. Sicepat32 SLS dashboard display

In Figure 2, the Sicepat32 SLS dashboard displays the SLS Entry menu used by the user to input the field data collection results in each Local Environmental Unit (SLS), a graphical bar displays the field progress of the officers in each Regency/ Municipality. For admin roles, there are data export and import menus, which can be seen in Figure 3. The export and import data menus are used to retrieve raw data per SLS and upload data from field data collection. Export to excel becomes one of the features that facilitate users.

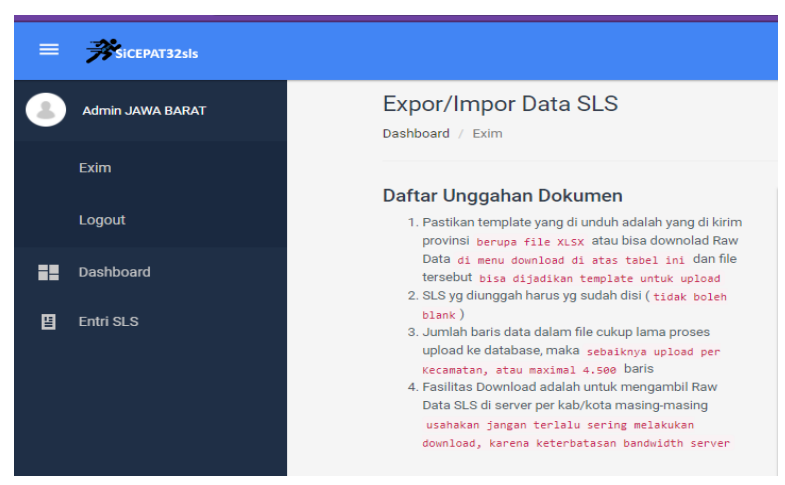

Figure 3. Export and Import Menu

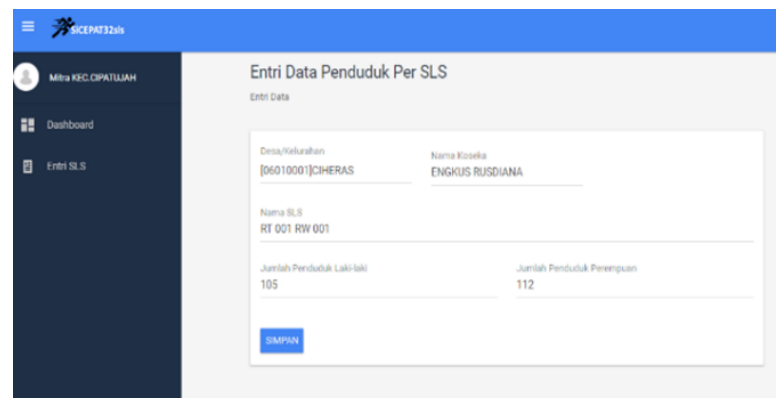

Figure 4. Display Data Entry

Figure 4 Display Data Entry used by users to input data from the field. The user must first select the regional identity including the Village code, the name of the local environmental unit, the name of the Head of the Local Environmental Unit. 
Then Sicepat32 SLS users are required to fill in the number of male and female residents in the SLS.

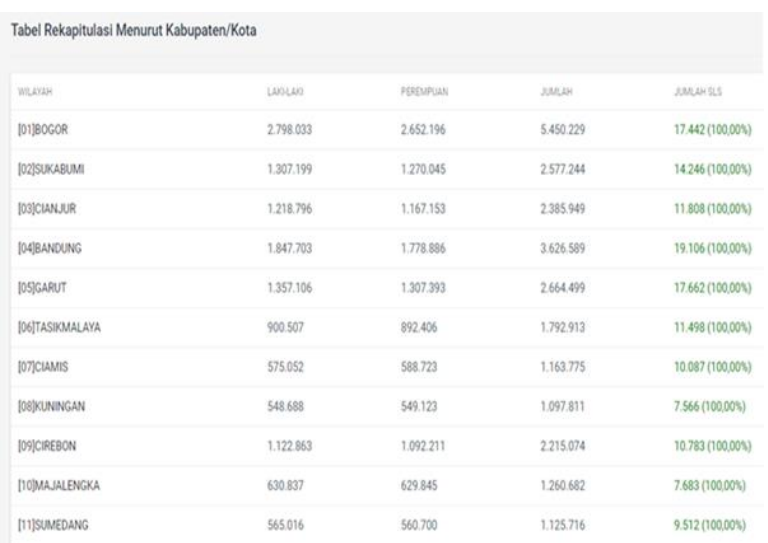

Figure 5. Recapitulation of the Number of Men and Women

In Figure 5. Recapitulation Number of Men and Women presented with a table visualization consisting of Regency/ Municipality columns, cumulative male population, cumulative female population, and progress of SLS that has been completed. From here, decision-makers such as the Head of the Office can see which areas have not been completed, so they can find out what problems are happening in the field. From this information, the Head of the Office can determine the next step whether special action is required in the area. This is the main point why Sicepat32 SLS became an early warning system for 2020 Population Census data processing.

\section{Pieces Framework Measurement Results}

From the results of the questionnaire data processing, the average score of the Sicepat32 SLS satisfaction level was obtained based on the domain contained in the PIECES Framework which is presented in Table 4 below:

Table 4. Score results based on Domain

\begin{tabular}{cccc}
\hline No. & Aspect / Domain & Score & Predicate \\
\hline $\mathbf{1}$ & Performance & 4.07 & Satisfied \\
\hline $\mathbf{2}$ & $\begin{array}{c}\text { Information and } \\
\text { Data }\end{array}$ & 4.17 & Satisfied \\
\hline $\mathbf{3}$ & Economics & 4,1 & Satisfied \\
\hline $\mathbf{4}$ & $\begin{array}{c}\text { Control and } \\
\text { Security }\end{array}$ & 4.03 & Satisfied \\
\hline $\mathbf{5}$ & Efficiency & 4.18 & Satisfied \\
\hline $\mathbf{6}$ & Services & 4.18 & Satisfied \\
\hline
\end{tabular}

Analysis of the results of data processing can be explained as follows:

\section{Performance}

In the 2020 Population Census activity, the user is very difficult to map which areas have not been completed or areas where the population is very far from the projection data. But after using Sicepat32 SLS, users can immediately see which area needs priority handling.

\section{Information \& Data}

In the field data monitoring process, the user will access the SP2020 dashboard which cannot display SLS data information in real-time. However, after using Sicepat32 SLS, users can view tabs directly on the dashboard or save them as Microsoft Excel files.

\section{Economic}

Previously, users had to send images of the results of their data collection via Mobile Capture. And the process of sending these images requires a lot of data packets and a long time. This happens because the networks in each region are different. By using Sicepat32 SLS, users only need to input SLS in the form of the number of male and female residents, supported also by import facilities with excel which make it very easy for users and are familiar on the user's side. This shows a positive indication from an economic point of view that the use of Sicepat32 SLS does not require a lot of money and a short time.

\section{Control \& Security}

At this control and security stage, Sicepat32 SLS has good enough control to protect existing data. One of them is using the login menu with 2 roles and a key generate when the user enters data. The program can only be accessed by the Census Coordinator as a user and IPDS Section as the admin and will also verify the results of the data input entered by the officer.

\section{Efficiency}

Mobile Capture has a high frequency of gadget usage as well as large enough storage. This results in inefficient work to get information quickly. Officers who have less storage space on their gadgets will have difficulty when the storage space is at full capacity and will cause hang/ errors. After using Sicepat32 SLS, field officers don't need to think about the storage space on their gadgets anymore. They only need to access Sicepat32 SLS via the website and then input data in the field. From this efficiency in terms of time can be seen with the Sicepat32 SLS, the time will be relatively fast to get information up to the small level.

\section{Service}

Sicepat32 SLS can quickly and responsively provide data on the number of population per area and can be seen the achievements of each area. 


\section{CONCLUSION}

From the results of problem identification and the calculation of the results of data processing in this study, it can be concluded that The PIECES Framework analysis method consists of 6 aspects/ domains of Performance, Information \& Data, Economics, Control \& Security, Efficiency, and Service in measuring the level of satisfaction of Sicepat32 SLS users, the score for the level of satisfaction is obtained. Domain Performance got a score of 4.07 with the Satisfied predicate, the Information and Data domain got a score of 4.17 with the Satisfied, the domain Economics got a score of 4.1 with the Satisfied predicate, the Control and Security domain got a score of 4.03 with the Satisfied predicate, domain Efficiency obtained a score of 4.18 with the satisfied predicate and the Service domain got a score of 4.18 with the satisfying predicate.

From the results of calculations and analyzes that have been carried out, it shows that Sicepat32 SLS can already be said to have the advantage and speed of processing data and displaying it in realtime graphical form, but there is a need for improvement and better development to support activities at the BPS Regency/ Municipality. Rapid Enumeration and Evaluation Information System of 2020 Population Census (Sicepat 32 SLS) based on the PIECES Framework has been able to provide satisfaction to users.

\section{REFERENCE}

Aji, S., \& Hidayatullah, A. (2019). Analisis Kepuasan Pelanggan Terhadap Kualitas Pelayan Aplikasi Gojek Dengan Metode PIECES Framework. Jurnal Sistem Informasi, $x, 1-7$. Retrieved from http://ojs.stmik-borneo.ac.id/index.php/JSIm/article/view/46

B Indra G, Hayatullah H, S. A. (2013). Analisis teknik Operasional Sistem Jaringan LAPAN Bandung Menggunakan Metode Pieces. Palembang.

BPS Provinsi Jawa Barat. (2021). Potret Sensus Penduduk 2020 Provinsi Jawa Barat Menuju Satu Data Kependudukan Indonesia. Bandung.

Dewi, A. R. (2018). Analisis Sistem Informasi Pengolahan Data Nilai Mahasiswa Menggunakan PIECES pada Prodi Sistem Informasi. Query, 5341(October), 37-46.

Dwiyantoro, D. (2019). Analisis dan Evaluasi Penerapan Sistem Informasi Smart Library AMIKOM Resource Centre dengan Metode Pieces Framework. Tik Ilmeu: Jurnal Ilmu Perpustakaan Dan Informasi, 3(2), 109. https://doi.org/10.29240/tik.v3i2.962

Fatoni, A., Adi, K., \& Widodo, A. P. (2020). Framework and Importance Performance Analysis Method to Evaluate the Implementation of Information Systems. 15007, $0-10$.

Fatta, H. Al. (2007). Analisis dan Perancangan Sistem Informasi. Yogyakarta: Andi Offset.

Hadisaputro, E. L., \& Setyaningsih, E. (2019). Analisis Terhadap Kepuasan Mitra GO-JEK Driver Kota Balikpapan Menggunakan Framework PIECES. J-Sim: Jurnal Sistem Informasi, 2(April), 23-28. Retrieved from http://ojs.stmik-borneo.ac.id/index.php/JSIm/article/view/32

Jogiyanto, H. M. (2017). Analisis dan Desain (Sistem Informasi Pendekatan Terstruktur Teori dan Praktek Aplikasi Bisnis). Penerbit Andi.

Lokapitasari Belluano, P. L., Indrawati, I., Harlinda, H., Tuasamu, F. A. ., \& Lantara, D. (2019). Analisis Tingkat Kepuasan Pengguna Sistem Informasi Perpustakaan Menggunakan Pieces Framework. ILKOM Jurnal Ilmiah, 11(2), 118128.

https://doi.org/10.33096/ilkom.v11i2.398.1 18-128

Robert S. Kaplan; David P. Norton. (2000). Balanced Scorecard: Menerapkan Strategi Menjadi Aksi. Jakarta: Erlangga.

SIS, D. (2020). Panduan Aplikasi Mobile Capture SP2020. Jakarta: BPS.

Sugiyono. (2015). Metode Penelitian Pendidikan: Pendalaman Kualitatif, dan R \& D. 229.

Supriyatna, A., \& Informatika, J. M. (2015). PERPUSTAKAAN DENGAN MENGGUNAKAN PIECES FRAMEWORK. XI(1), 43-52.

Sutabri, T. (2012). Analisa Sistem Informasi. Andi Yogyakarta.

Takdir, T. (2019). Analisis Kinerja, Kualitas Data, dan Usability pada Penggunaan CAPI untuk Kegiatan Sensus/Survey. Jurnal Aplikasi Statistika \& Komputasi Statistik, 10(1), 9. https://doi.org/10.34123/jurnalasks.v10i1.1 98

Tullah, R., \& Hanafri, M. I. (2014). Evaluasi Penerapan Sistem Informasi Pada Politeknik LP3I Jakarta Dengan Metode Pieces. 4(1). 